\title{
Catalan Government Popularity. An example of Economic Effects on Sub-national Government Support
}

\author{
Aida Díaz \& Clara Riba *
}

* Aida Díaz is PhD student at the Universitat Autònoma de Barcelona, Departament de Ciència Política i de Dret Públic.

Address: Edifici B, 08193 Bellaterra, Spain.

Tel: (34) 934900873

Fax: (34) 935812439

E-mail: aida.diaz@cpdp.uab.es

* Clara Riba is lecturer at the Universitat Pompeu Fabra, Departament d'Economia i Empresa.

Address: C. Ramon Trias Fargas 25-27, 09005 Barcelona, Spain.

Tel: (34) 935422713

Fax: (34) 935421746

E-mail: clara.riba@econ.upf.es 


\begin{abstract}
The aim of this essay is to deal with economic voting in contexts of multilevel governance and to be a contribution to the debate on attribution of responsibilities in popularity functions literature. We use aggregate and individual data from Catalonia in order to analyse the relation between the state of the economy and the support for a substate government. The empirical analysis shows that the responsibility hypothesis works in regional governments without explicit macroeconomic competencies. We have also considered the evaluations of government performance on certain specific policies in order to clarify and determine the factors that drive Catalan government support. The article considers the implications of the findings for future attempts to model party support in a context of the European Union.
\end{abstract}

\title{
JEL: D72.
}

Keywords: Economic vote, popularity functions, attribution of responsabilities, grievance asymmetry.

This paper has been written in the context of a research project on Popularity Functions in Spain supervised by Professor Josep M. Vallès at the Universitat Autònoma de Barcelona. This research has been funded by the Comité Interministerial de Ciencia y Tecnología (CICYT) and the Institut de Ciències Polítiques i Socials (ICPS). LINE-STAFF generously shared the public opinion data this article is based on. We thank all of these for making this paper possible.

A preliminary version of this work was presented at the 1999 ECPR Joint Sessions of Workshops in Manheim. The authors are grateful to all participants in Workshop 12 on "Political Institutions: Intermediates between Economics and Politics" for their useful comments. 


\section{ECONOMIC CONDITIONS AND GOVERNMENT SUPPORT}

In the late 1960s it became a common journalistic assumption that economic factors play an important role in determining government popularity. In March 1968, Harold Wilson asserted "All political history shows that the standing of the government depends on the success of its economic policy" (Heath et al, 1991: 159). As can be seen the notion of some kind of link between economic conditions and government support is firmly established within scientific community and the literature dealing with it has grown considerably, being now very extensive ${ }^{1}$.

Most popularity functions assume the classical "reward-punishment" model of the type suggested by V. O. key (1968). It is simple: if economic conditions are good, so the most common argument goes, the electorate will reward incumbents, while it will punish them if economic conditions are less than satisfactory. Political actors are usually well aware of their standing with the mass public, as well as the potential political consequences of inadequate economic performance. It has been often alleged that governments, therefore, attempt to influence economic policy outputs by manipulating the levels of fiscal and monetary policy. The outcomes of such attempted manipulations (that are the economic conditions attained) serve as guidelines for the electorate's evaluations of government performance. The implicit assumption behind this statement is that the government is directly responsible for economic conditions. Butler and Stokes had already argued that government responsibility for the economy is a fundamental assumption of the dialogue between parties and the electorate.

\footnotetext{
"Modern electorate tend to solve (the) problem of causal reasoning by assuming that certain causal relationships must exist rather than by discerning what they are. Electors focus their attention primarily on certain conditions, which they value positively or negatively and simply assume that past or future governments affect them. The public can call for a governments dismissal in economic hard times just as it calls for a team manager's dismissal in a losing season, in each case concluding that causal relationships must exist without knowing in detail what they are" (1976:25).
}

This hypothesis contrast with the strict notion of rationality that would consider that voters differentiates between changes attributable to the government and those caused by other factors. For instance, the rise on the oil price in the seventies affected the major 
part of Occidental economies, a factor over which many governments had no influence. In that case, it would be unfair to blame the government for that situation.

The notion of responsibility is of prime importance in this kind of studies and emerges as a key condition in joining economic grievance to political preferences (Lewis-Beck and Eulau, 1985). One of the assumptions that lay behind the reward-punishment hypothesis is that there is a "clarity of responsibilities" in terms of which party (or parties) is (are) responsible for macroeconomic policy and performance (Powell and Whitten, 1993). Without clarity of responsibility, there is no reason that there should be any correlation between party support patterns and the economy. A second assumption behind the hypothesis, is the existence of a viable and credible opposition to which citizens may approve or vote if they don't like the incumbent party“s performance. As David Sanders states, if, for whatever reasons, voters believe that the opposition fail to offer a credible alternative to the incumbent party, then, regardless to the political complexion of the incumbent, macroeconomic performance need not necessarily damage the government (1998:8). Therefore, in conditions of non-credible opposition there should be no correlation between party support and the state of the economy. For instance, this sort of situation might have existed in England during 1980's and 1990's. By this time, the labour party was immerse in a crisis and had serious problems of credibility. It was not seen as a potential governing party (Seyd, 1997; King, 1997). However, the lack of a clear government alternative doesn't seem to be sufficient in order to nullify the effects of the reward-punishment model. In fact, several studies have showed how the conservatives were affected by macro-economy (Sanders et al., 1987; Clarke et al., 1995). In the Spanish case, the lack of a credible alternative has also contributed to the Socialist hegemony during the eighties (Fraile, 1999).

It turns out that the question of why and how people should attribute economic changes to the incumbent's action remains unclear. It is dubious that the responsible model, which it is in part based on the British parliamentary system, works in a similar way on other political contexts where the political control is not in the hands of a single party ${ }^{2}$. As Anderson points out "responsibility is frequently shared by competing political actors though mechanism such as coalition government or simple obscured because of multiple levels of decision-making and political control" (1999:3). 
Although the literature on vote and popularity functions is extensive (Norpoth, LewisBeck \& Lafay, 1991; Nannestad \& Paldam, 1994), the question of assignment of responsibility hardly ever has been addressed. Powell \& Whitten (1993) and Anderson (1995) consider the structure of credit and blame is filtered by the political context. Specifically, they use some measures of institutional complexity (single or multi-party government, bicameral opposition, share of parliamentary power, party strength, number of parliamentary seats and number of cabinet posts) in order to clarify the attribution of responsibilities. Other line of research has addressed the issue of clarity of responsibility in contexts where the political power is shared or divided into several institutions. For instance, some authors have modelled popularity functions for the French case during the cohabitation period, with the President and the Prime Minister belonging to different political parties (Lewis-Beck, 1988; Lafay, 1991). Other, have concentrate their efforts in the attribution of responsibilities in cases of divided government in the United States (Leyden \& Borrelli, 1994; Alesina \& Rosenthal, 1995). However, studies on popularity functions for sub-national governments in a context of multilevel governance are almost non-existent.

By using Catalan aggregate and individual data, this paper will focus in two aspects. First, it will inquire whether, and to what extent, economic variables statistically correlated with state-governments exhibit the same effect on regional governments without important explicit competencies in this area. Second, it will try to clarify the underlying factors that shape government support at the individual level, bringing some light into the attribution of responsibilities debate.

The paper begins with an overview of Catalan politics. Next, with time series analysis, we try to find out if economic conditions drive sub-national government support. Then, individual level data is used to strength the macro results and to discern whether voters really attribute economic responsibility to this government, using evaluation of policies as an alternative to elucidate government responsibilities. The conclusion considers the implications of the findings for future efforts to model party-support in a context of multilevel governance. This can be the most predictable scenario in the European Union 
in some year's time when part of the power of the estate-based governments will be transferred to a European supranational institution.

\section{AN OVERVIEW OF CATALAN POLITICS}

Democracy brought a new form of territorial organisation of political power in Spain, which is known as "Autonomic State" or "State of the Autonomies (self-governing communities)". This is undoubtedly one of the Constitution's main innovations, which aims to solve the historic necessity to articulate Spain's national and cultural plurality into a new political unit. This new form of territorial organisation implies a vertical distribution of the state power between the central institutions and the territorial ones, granting to each of them some competencies, bodies and resources (Fossas \& Colomé, 1993). Therefore, the Autonomous Communities (AA.CC.) are territorial entities with a legal-constitutional power ${ }^{3}$.

The approval of the Catalan Statute of Autonomy in the 1979 referendum made possible to held the first autonomous elections a few months later, on March $20^{\text {th }} 1980$, converting the Generalitat (name given to the Catalan cabinet) in the fundamental basis and most symbolic expression of the Catalan self-government ${ }^{4}$. Since then, five elections, with four completed full term governments, have been held. The autonomous elections have been the basis for the legitimisation of the Catalan autonomy and for the Spanish democracy itself. As it was impossible to imagine an autonomy in Catalonia without a democratic framework in Spain, it is not possible to imagine a stability and a consolidation of democracy in Spain without a Catalan autonomy based in the elected nature of its own institutions. The Catalan government is then the fundamental basis and most symbolic expression of the Catalan self-government, as well as the expression of Spanish democracy.

This epoch of democratic and autonomous stability constitutes a period long enough to allow us, with assurance, to depict some features and make some reflections on the autonomous electoral processes and to study the government support in Catalonia. The nationalist coalition Convergència i Unió $(\mathrm{CiU})$ has been in power since the first 
democratic elections and, from 1984 to 1995 , with the absolute majority of parliamentary seats $^{5}$. The hegemony of CiU in Catalan politics at the electoral level, as well as at the institutional level, can be explained by a set of factors. Among them, it can be cited: the strength of the governing coalition and the stable unity of the parties which compose it; the lack of an effective opposition; the existence of a strong personalisation of the campaigns; and a "presidentialisation" of Catalan politics (Vallès \& Molins, 1990; Pallarès \& Font, 1995) ${ }^{6}$.

Nevertheless, the support which appears behind CiU's absolute majority in the autonomous level, is unique compared to other type of elections in Catalonia. Thus, in the general elections the winning force has always been the Catalan Socialist Party (PSC) which is connected with the Spanish Socialist Party (PSOE). In the local elections, the global triumph is "divided". This changes are produced by the phenomena of "differential abstention" and "dual vote", that have acquired big significance in Catalan politics (Montero \& Font, 1991; Riba, 1995) ${ }^{8}$.

Apart from the above phenomena but connected with it, the electoral alignments and the interplay competition have been structured in the space defined by the interrelation of two main attitudinal axes. The Left/Right continuum is the main dimension of the political conflict as it occurs in most of the European party systems, while the axis of Nationalism (or the subjective national identification) expresses the conflict derived from the problems related to national integration between Catalonia and Spain. The government party $(\mathrm{CiU})$ political discourse adopt moderate tones in relation to nationalism, with irregular emphasis according to the circumstances, while at the socioeconomic level it is located at the centre of the Left/Right axis adopting a liberal point of view. Its discourse is a really economic one, emphasising the role of businessman and small and medium-size companies in the development of the country. For instance, this economic discourse can be seen in the reason given by the nationalist coalition for supporting the State Government. The pacts reached in 1993 with the socialist party and from 1996 with the Popular Party have been explained by the necessity of an economic stability in order to achieve the convergence criteria for the entrance to the European Currency Unit (EURO) ${ }^{9}$. 


\section{THE DYNAMICS OF CATALAN GOVERNING-PARTY APPROVAL}

In this section, we shall try to see if we can apply the conventional wisdom that the state of the economy drives political support to a sub-national government. However, before starting our specification, it is important to point out one fact: the importance of the political context on models of political support, as it structures the assignment of credit and blame. Therefore, Catalan politics have to be placed in the Spanish general political framework outside which its dynamics cannot be understood. This would lead us to include in the model variables aggregated at the Catalan level reflecting the Spanish economic and political situation. Although we have aggregate macroeconomic Spanish indicators, we do not dispose of survey data on subjective evaluations of Catalan people for the Spanish economy. So, we will not focus on them. Our aim is to see if we can apply the hypothesis tested in State governments to regional ones. We don't want to suggest economic is a decisive factor but examine whether it influences or not.

The evaluations of the work carried out by the Generalitat are exceptionally positive, even if we compare it with the evaluation Catalan people make of the central government (Montero \& Font, 1991), or with the evaluations the citizens of other Autonomous Communities make of their respective autonomous governments (Montero \& Torcal, 1992). In addition, this positive evaluations goes beyond the limits of the loyal CiU electorate and it is high among the dual voters the coalition receives (Canals, Pallarès \& Virós, 1991). One of the factors that help to explain such popularity is the structure of government responsibilities of the Autonomous Communities. These act mainly as lending services institutions, not having to participate in collecting taxes, which appears to be a favourable framework for their popularity being higher than the one of other administrations with collecting functions.

\section{Data and measures}

In order to account for the popularity of the nationalist party during its mandate we use aggregate monthly data between May 1991 and October $1995^{10}$. The use of monthly 
data, instead of quarterly data, carries certain advantages as well as disadvantages. On the one hand, there is more "noise" with monthly data, which can produce a reduction of the fit of the model. On the other hand, by aggregating monthly data into quarterly data we lose information and the number of observations decreases. In this case, we have considered that the benefits overweigh the inconveniences.

The period of time analysed includes an autonomic election in 1992 and finishes a month before the 1995 elections were held. From an economic point of view, this period is characterised by an important economic crisis, which started at the end of 1992 and touched its bottom in 1994. In the political sphere, it is important to consider the governmental support given by $\mathrm{CiU}$ to the socialist state-government after the 1993 general election and the electoral success of the Popular Party in the European elections of 1994. This conservative electoral victory finished with the socialist hegemony since 1982 in Spanish politics ${ }^{11}$. It continued with the "search and destroy operation" (guerra de "acoso y derribo") towards the government of Felipe Gonzalez and towards its nationalist partners, CiU and the PNV (Basque Nationalist Party), which had already started two years earlier. This period is also characterised by the existence of an atmosphere of extreme political and social tension, fuelled by political scandals ${ }^{12}$.

Our dependent variable, which will be used as an indicator of popularity, is the evaluation of the Catalan Government in a ten-point scale. Figure 1 shows a relatively high valuation of the "Generalitat" between May 1991 and October 1995, with a mean of 6,19 and a median of 6,37 .

As we have already said, the analysis will include Catalan as well as Spanish data indicators in order to consider the context. Taking into account that media is an important source of information and that most of the television channels and press are state-wide, it could be possible that people's perceptions were more influenced by the Spanish economic indicators than by the Catalan ones. By introducing this two kind of aggregated indicators, we wanted to test either people is more influenced by their social or territorial setting or by the national context. 


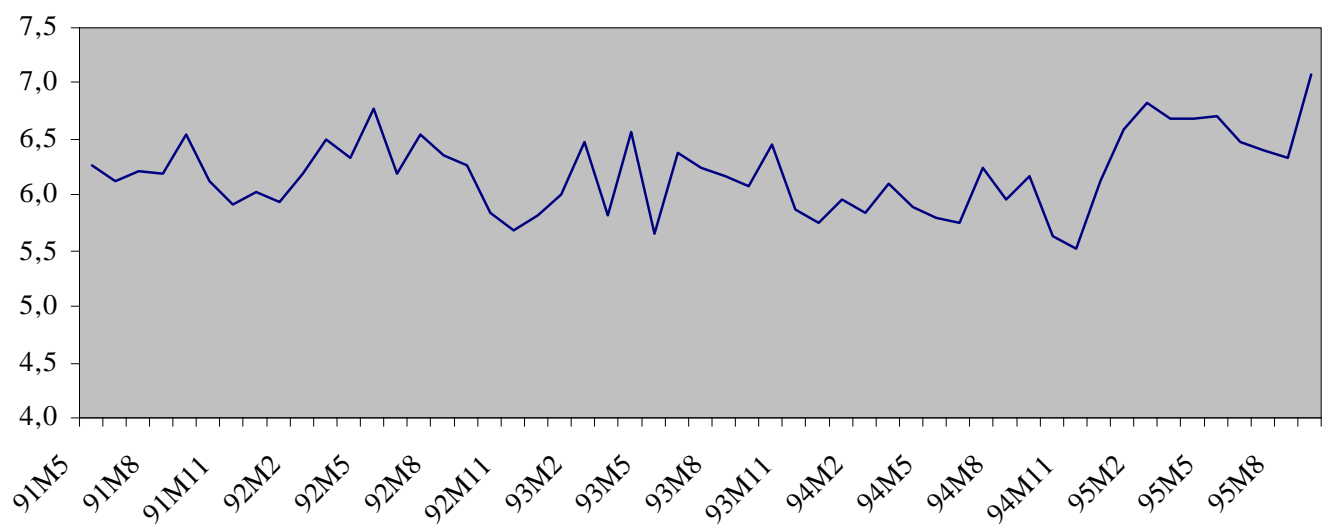

Monthly unemployment, inflation and interest rates, provided by the Instituto Nacional de Estadística (Spanish Statistic Institute), measure economic effects on government support. As comparative research shows, unemployment and inflation are by far the most widely used and the most consistently significant indicators of macroeconomic performance. Public opinion also shows that they are the economic issues of most concern to most people and they are highly salient by the press. Apart from introducing the Catalan and Spanish unemployment rate independently, we have also included their difference. By this strategy we wanted to see if electors attribute the difference between these two rates to the economic record of the Catalan government.

An important recent innovation in popularity model specification has been the inclusion of "subjective economic variables", that is, public evaluations of national and personal economic conditions. At this respect, we have included as explanatory variables measures of economic evaluations in terms of retrospective and prospective, egotropic and sociotropic perceptions for Catalan and Spanish situation. As regional citizens' evaluations of the Spanish economic situation could not be found, we have used Spanish economic evaluations obtained from representative surveys of the whole Spanish population. 
It would be unreasonable to expect economic variables alone to be sufficiently powerful to explain changes in aggregate support for the Catalan government. Politics is a crucial factor that partially determines the dynamics of support (Eulau \& Lewis-Beck, 1985). For that reason, we have included a political component in the model. It consists in a set of dummies. Three of them signal elections (1992 autonomic, 1993 General and 1994 European elections). Others are several variants of a political scandal affecting the government (the case Cullell) ${ }^{13}$. One stands for the Olympic Games held in Barcelona in 1992. Four are alternative specifications of CiU's support to the Spanish socialist Government. Finally, there are several variables modelling electoral cycles and tendencies.

\section{Model specification}

The literature of economic voting and popularity functions is not unanimous about the convenience of using levels of the variable or the changes of those levels as predictors of government support. Using levels of the variables is full of problems and difficulties because of the non-stationarity phenomenon ${ }^{14}$. If the variables are non-stationary modelling them in level form will produce serious inferences and generate "spurious regressions" where regression coefficients appear statistically significant even when the variables are in fact absolute unrelated. To solve the spurious regression, political scientists have differenced the data. Differencing the data means removing the possible trends of the data and then, throwing away potentially useful information that may contain useful proofs of causal relationships between variables. Yet, if the variables are differenced, a possible evidence of an association is removed. As Sanders et al. point out it is possible that the trends of two variables reflect a long-term causal relationship, although the deviations from the trends (the short term fluctuations) are entirely unrelated (1987: 87). Moreover, from a theoretical perspective, it is reasonable to think that people knows the ups and downs of the variables rather than the real values. Consequently, either from the technical or the theoretical point of view, it seems preferable to use the changes of the variables rather than their levels.

We employ Dickie-Fuller unit root test ${ }^{15}$ to determine whether the series are stationary or non-stationary in which case must be differentiated. Analyses covering this period 
reveal that the unemployment rates and the economic subjective perceptions are nonstationary but become stationary at their first difference (Table 1).

Table 1: Unit Root Tests for Stationarity (1991M5 - 1995M10)

\begin{tabular}{ccc}
\hline & Original series & Differenced series \\
\hline Government support & -3.95 & ---- \\
Catalan macroeconomic data & & \\
Unemployment & $-0.24^{*}$ & -4.32 \\
Inflation & -9.3 & --- \\
Spanish macroeconomic data & $-0.14^{*}$ & -4.65 \\
Unemployment & -8.25 & --- \\
Inflation & -4.03 & ---- \\
Catalan economic evaluations & -4.39 & ---- \\
Personal retrospective & $-3.05^{* *}$ & -11.06 \\
Personal prospective & $-1.49^{*}$ & -12.07 \\
National retrospective & $-1.88^{*}$ & -13.10 \\
Spanish economic evaluations & $-0.53^{*}$ & -11.14 \\
Personal retrospective & $-1.83^{*}$ & -12.57 \\
Personal prospective & & \\
National retrospective & & \\
National prospective & -2.88 & \\
\hline pritical values for Unit Root Test & -3.47 & \\
p $\leq 0.05$ & &
\end{tabular}

* Fails to reject the null hypothesis of unit root, $\mathrm{p} \leq 0.05$

** Fails to reject the null hypothesis of unit root, $p \leq 0.001$.

Note: All tests were conducted with constant but without trend.

To avoid misspecification, we follow the Hendry methodology for model building (Hendry \& Richard, 1983) ${ }^{16}$. Model parameters are estimated using OLS procedures. We have also included the level of support for the government during the previous month (Govt-1). This specification represents a distributed lag model, using the Koyck transformation (Harvey, 1981), which has become a standard approach to the analysis of government popularity. From a technical point of view, this approach is reasonable due to the inherent interdependence of the observations in a series and the persistent problem of autocorrelation in time series functions. Time creates dependence not only between variables but also within them. This idea corresponds to the reality of government popularity. As far as our opinion today (i.e.: on politicians, economic evaluation) 
typically is very much like the opinion we had yesterday, apart from something different. In order to control for lagged effects, the lagged dependent variable is included as a control measure. This formulation is convenient because it means that only current values of the independent economic variables need to be included in the model instead of a more complex lagged model formulation (Anderson, 1995:93). Moreover, the level of government support during the previous month captures the lagged effects of the independent variables, which can remain in the future. The smaller of the coefficient for Govt-1, the shorter the memory of the system (Beck, 1991; McKuen, Erikson \& Stimson, 1992).

\section{Empirical results}

The model estimated is known as a partial adjustment of an autoregressive distributed lag specification (ADL-PA):

$$
\text { Gov }_{t}=\beta_{0}+\beta_{1} \text { Gov }_{t-1}+\beta_{2} \Delta \text { Caun }_{t-2}+\beta_{3} \Delta \text { Gret }_{t}+\beta_{4} \text { Cullell }_{t}+\varepsilon_{t}
$$

Where Gov $=$ Nationalist party support Caun $=$ Catalan unemployment rate; Gret $=$

Catalan economic retrospection; Cullell $=$ Political scandals; $\varepsilon=$ error term $\sim N\left(0, \sigma^{2}\right)$; $\beta_{0}=$ constant $; \beta_{1-4}=$ Regression coefficients .

The results (Table 2) show that the Catalan unemployment rate two months ago and Catalan general retrospection affect government support. It can also be seen that Spanish measures of the state of the economy do not appear in the model, neither do the difference between the Catalan and the Spanish unemployment rate. Only one political variable (the case Cullell) prove a statistically significant influence on approval ${ }^{17}$. The lagged endogenous variable is really small showing a certain instability of the dependent variable data.

It is well known the instability of the estimated coefficients in these models ${ }^{18}$. For that reason, we have also used recursive and rolling regressions in order to check how stable 
is our relationship ${ }^{19}$. Both analyses display a strong stability of the coefficients for all three variables, confirming the robustness of our model.

Table 2: Economic and political effects on Catalan party-support

\begin{tabular}{lcc}
\hline & Coefficient & t-ratio (sig) \\
\hline Constant & 4.96 & $7.08(.000)$ \\
Catalan government support (t-1) & .21 & $1.84(.071)$ \\
$\Delta$ Catalan Unemployment (t-2) & -.63 & $-5.05(.000)$ \\
$\Delta$ Catalan economic retrospection & .67 & $2.69(.010)$ \\
Cullell & -.46 & $-.508(.000)$ \\
& & \\
\hline Model diagnosis & & \\
$\mathrm{R}^{2}$ & 0.63 & \\
Adjusted $\mathrm{R}^{2}$ & 0.60 & \\
Durbin Watson & 2.02 & \\
A: Serial correlation (LM) & $12.111(.437)$ & \\
B: Functional form & $.54168(.462)$ & \\
C: Normality & $.80003(.670)$ & \\
D: Heteroscedasticity & $5.0791(.024)$ & \\
\hline
\end{tabular}

Note: A: Lagrange multiplier test of residual serial correlation; B: Ramsey's RESET test using the square of the fitted values; C: Based on a test of Skewness and Kurtosis residuals; D: based on the regression of squared residuals on squared fitted values.

From Table 2, we can conclude that Catalan aggregate economic conditions influence support to the Generalitat. In this sense, the model seems to perform according to the simple reward-punishment hypothesis. People attribute regional economic situation to their regional government regardless the competencies it holds.

However, the fact that Spanish indicators do not affect the popularity of the Catalan Government can be seen as somewhat astonishing. Even expecting that Catalan variables would have stronger effects on Catalan Government than the Spanish ones, we would not expect the latter variables to be insignificant. We know voters have a limited economic knowledge and therefore, it seems difficult they can distinguish between them. At this respect, it is worth to point out that a crucial issue in popularity functions is the problem of how perceptions are formed. In principle, there are several complementary sources of information. One of them is the personal experience and those of the relatives, friends and members of the community where the individual develops his activity. 
Another is the information that comes from the media. It has become common to assume that people may be willing to delegate their expectations' formation to others "advisers" such as the media. However, Weatherford (1983:161) has maintained that there is "no question that citizens have realistic, but firmly grounded impressions of their own personal financial condition, so that media influence might be confined to national economic conditions". Following the Weatherford's argument, probably the media influence more people' perceptions of the Spanish economy than the personal ones, and, for extension, that those of the Catalonia. The results of our analysis conform to the above thesis: in the Catalan case, people surroundings are more important than mass media in the generation of economic perceptions.

The fact that 'Catalan' retrospection outweighed the influence of 'personal' retrospection would easily located Catalan voters in the sociotropic group. In a temporal dimension the Catalan 'retrospection' locate them in the retrospective side. Although we recognise the theoretical appeal of the questions contended in those debates, we think that the interrelation between the four dimensions (general versus personal and retrospective versus prospective) is so strong that being one or another the variable which affects the support may be an accidental question. In this sense, Clarke et al. (1995) analysing competing models, find that personal expectations variants generally do well in the British case, although they do not outperform one or more alternatives incorporating other types of economic evaluations.

\section{POPULAR SUPPORT WITH INDIVIDUAL DATA}

The above results suggest that the economy influence sub-national governments. But are these aggregate findings compatible with the individual voter calculus of the naive reward-punishment theory? It is an ecological fallacy being committed? Maybe citizens don't perceive where the real economic power is. Maybe, they don't distinguish between the Spanish and Catalan economic government management. Maybe, they see the Generalitat as a central political economic authority. Moreover, many studies compare the variation on governmental approval over time with the rise and fall of a set of possible explanatory variables, assuming that people evaluate the government in terms of 
its performance regarding economic issues. But is this the case? Why people evaluate the government as they do?

In order to respond to these questions, micro-level analysis is especially important because they allow us to test the causal relations associated with aggregate popularity models and, consequently, validate our results. We must remind that popularity functions are basically descriptive. The models themselves serve for discover the factors that affect government popularity, but they do not really serve us to know what is the inherent process that generates the individual perceptions leading to this support. For that reason, the two bodies of research are intimately related to one another and they need each other in order to validate our hypothesis in a more conclusive way. We argument that the use of individual data can help us to strength the macro results. Hence, we are going to work now with individual level data with the objective to enlighten what are the factors that people take into account when they evaluate the government and to discern if Catalan voters really attribute economic responsibility to the autonomous government.

In our micro analysis we use a group of twelve questions about evaluation of specific policies carried out by the Generalitat, such as education, health, occupation, environmental policies and so $\mathrm{on}^{20}$. These questions provide us with more detailed information about the judgement citizens make of the different aspects of the governmental task and show the degree of salience the Catalan people give to this issues. We will use these items in order to explore the hidden factors in the attribution of responsibilities for government performance.

\section{Factors underlying evaluations of specific policies}

Evaluations of the government policies, where attribution of responsibilities look clear, can be a good method to validate our aggregate findings. Let us now turn to the set of variables that contains the citizens' perceptions about how well the different departments of Catalan government are ruling their competencies. We are interested in knowing what is the relationship between the general government approval and the evaluation of policies related to specific issues. Our hypothesis is that the opinions that citizens have of specific policies determine their evaluation of government performance. Looking at the 
values of the twelve issue-variables, we realise that they are fairly correlated. Hence, in this case, it seems sensible to assume that policies' evaluations are particular consequences of more general perceptions about how the government is doing in some main hidden aspects they consider important. That is, we hypothesise that there are some common latent factors underlying policies' evaluations and we are interested in highlight them. If we were capable to determine these factors, they could be used as predictors of the evaluation of government performance in a more parsimonious and accurate way than using the values of the initial policy-variables.

For the above-explained purposes, we have used the Factor Analysis technique. It permits to extract a group of uncorrelated factors that contain most of the variance of the original variables and eliminate the noisy on the data. An initial exploratory factor analysis of the twelve variables recording policy evaluations has determined the existence of three factors. One of them weights heavily in the "culture", "Catalan language" and "education" policy variables. As a result, we can recognise it as a cultural factor. The variables with more important weights on the second factor are "financial aid to firms", "occupation", "housing" and "public works". It seems clear that this is an economic factor. Finally, the third factor is strongly correlated with the "health" and "welfare" policy variables, which are related with social policies. Therefore, We will identify it as a social factor. The rest of the variables, "youth", "law and order" and "environmental policies", are somewhat correlated with the three factors related above, but they are less well explained by them. In consequence, we have decided no to include the last variables in a second confirmatory factor analysis. The three factors we found explain conjointly more than $65 \%$ of the total variance in policies' evaluation, being the percentage of variance explained for each factor quite similar: $25 \%$ the economic factor; $21 \%$ the cultural factor; and $19 \%$ the social factor.

Hence, we can conclude that the evaluations that citizens give to specific policies carried out by the departments of the government are mainly concretions of more general evaluations based on its perceptions on cultural, economic and social governmental performance. 
Figure 2. Factors underlying evaluation of policies

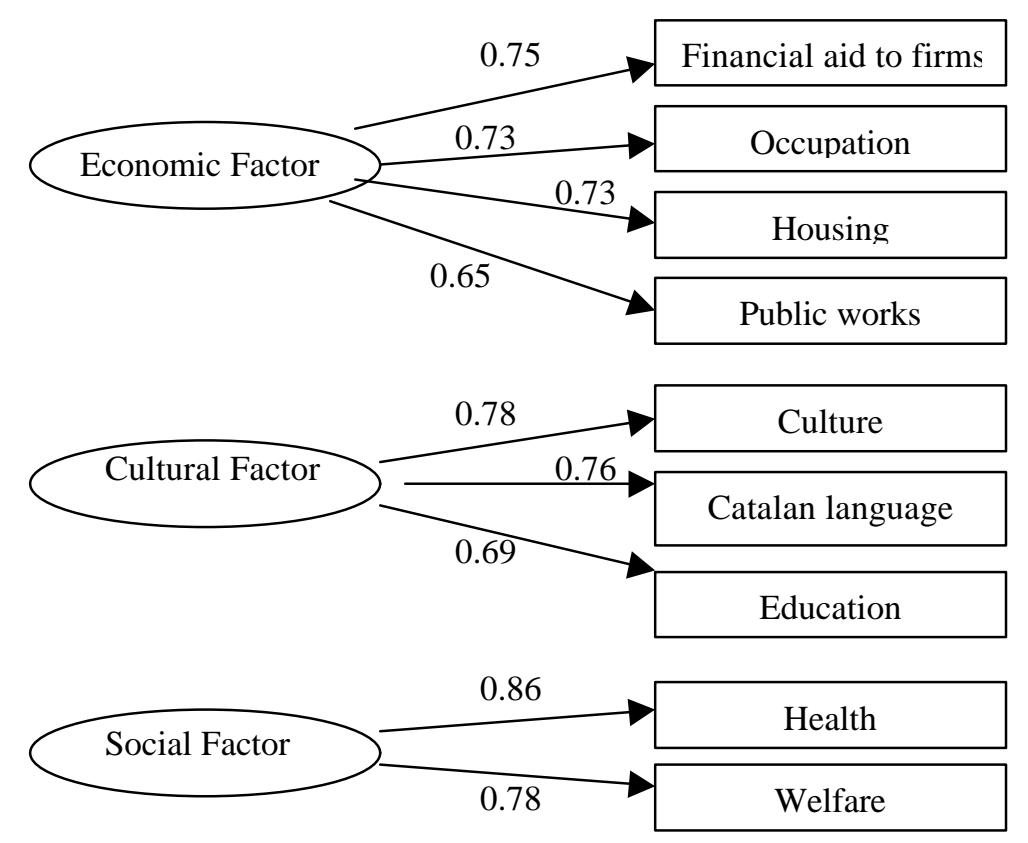

The economic factor is the most important of the three. From an external point of view, it can sound somewhat strange that citizens give importance to economic policies in the evaluation of a government with important competencies in other issues but with almost no power in economic matters. However, this fact is consistent with our results at the aggregate level that show the significance of Catalan unemployment and economic retrospection on regional-government support. The importance that Catalan citizens assign to economic issues is perfectly reflected in their statements. When asked in an open question of the same survey about what is the more important problem in the country, $64 \%$ of citizens say unemployment and $12 \%$ mention other economic issues as economic situation, housing or taxes. That is more than three quarters of respondents $(76 \%)$ considers that the main problems of the country are of economic nature. On the other hand, when asked about the problems that worried them at a personal or familiar level, the unemployment concerns descent until 19\%. However, there is a $17 \%$ of respondents that considers the instability of jobs as problem and $15 \%$ more that are preoccupied for the rest of the economic issues. In all, more than half of surveyed (51\%) is worried about economic issues at their personal or familiar level. 
Another aspect to point out is that, when asked about what is the most important action carried out by the Generalitat during the last few months, there are $60 \%$ of nonrespondents. However, more than half of those who give some answer cite actions related with the economy (45\% say public works and $6 \%$ other issues as incentives to creating jobs or aids to create new enterprises).

In sum, Catalan community has a greater concern about economic issues. Three quarters of people considers them as the most important problems that have to face our country and half is preoccupied for economic aspects affecting his familiar life. Finally, half of those who are capable to indicate an important achievement of the Generalitat, report public works or economic policies. In consequence, is coherent that, when evaluating the results of specific policies, they take into account the underlying economic factor.

The existence of a cultural factor in policy evaluations is coherent with the reality of politics in Catalonia. In fact, the nationalists parties and, in particular, CiU claim for a greater level of autonomy, due to the so called "differential fact" of the region based on the historic and linguistic Catalan characteristics. It is quite normal that such a subnational government emphasises all the cultural policies oriented to increase citizens' "national" identity. By strengthening Catalan identification, its support for negotiating with the Spanish government the transference of more power increases. In such a circumstances, cultural policies acquire great importance and people recognise it when consider them as one of the main aspect of government evaluation. For example, there has been recently a great debate in Catalonia concerning the politics of language due to the discussion of a new Language Law in the Catalan Parliament. In contrast to the 1983 Linguistic Normalisation Law that was reached by consensus, there were opposite views between parties about the necessity and the content of the 1998 Linguistic Policy Law. Once the ancient law succeeds in that almost all people understand Catalan, the new one intends to increase its use among people and institutions. And this goal was seen as a threat for an important sector of Spanish speakers living and working in Catalonia. The supporters and opposing to this aim have different views about the Generalitat record on cultural aspects and, consequently, will report different positions in the evaluation of language policies. 
Finally, it is also quite coherent the presence of a social factor as Catalonia is one of the autonomous communities in Spain with a higher level of competencies, among them health and some welfare policies. On the one hand, health policy is very important not only because its impact on dairy life of people and the great volume of resources devoted to it but also because the innovation in the lending of service introduced by the Generalitat. In fact, Catalonia was the pioneer in Spain in introducing some aspects of private management in the service of public health. This initiative has been somewhat controversial because while for some people it enhances the service for others is a way of privatisation one of the pillars of the welfare state. On the other hand, welfare policies are important not because of the resources devoted to it (somewhat scarce) but for the symbolic and propagandistic use of them. There is a Department of Social Welfare that carries out some social policies and, specially, it distributes financial aids among institutions, associations and non-governmental organisations that works in favour of the needed. The character of the mainly beneficence of these policies and the lack of transparency in the distribution of the subsidies has generated some criticisms. As a result, there are different opinions about the goodness of social policies carried out by the Generalitat and this social aspect of the government record is taken into account by citizens when evaluate its policies.

Once we have found three underlying factors of citizens' policies evaluations, the question is are they related with the attitudinal axes that structure the political conflict in Catalonia? The answer is yes. As we have already said, there are two independent political dimensions in Spain. The first is the well-known Left/Right dimension that embodies different cleavages, such as economic, social or defence (Budge \& Farlie, 1983; Padró-Solanet, 1993). The second is the nationalist dimension related with the process of political decentralisation. While the economic and social factors are related to the Left/Right dimension, the cultural factor is associated with the latter ${ }^{21}$.

\section{Influence of policy evaluations on governing party support}

In this section, we use the three factors underlying evaluations on government performance in order to predict governmental approval. In addition to them, we use as a 
control variables leadership (measured by presidential evaluation) and reported vote for $\mathrm{CiU}$ in the last autonomous elections ${ }^{22}$.

Table 3 shows the results of the estimation of a logistic regression predicting governmental approval from the values of the cited variables. The model is highly significant and predicts correctly $90 \%$ of the cases. All factors are significant at the 0,001 level and its coefficients are positive. It means that the higher the evaluation in economic, cultural and social policies, the higher the probability to approve the government. Similarly, the leadership's coefficient is highly significant and positive, meaning that the higher the President's evaluation, the higher the probability to approve the government.

Table 3: Logistic regression for governmental approval

\begin{tabular}{lrr}
\hline & Coefficient & Wald (sig) \\
\hline Evaluation of government performance & & \\
$\quad$ Economic factor & $.8822 * * *$ & $34.49(.000)$ \\
$\quad$ Cultural factor & $.9991 * * *$ & $40.99(.000)$ \\
$\quad$ Social factor & $.5473 * * *$ & $13.75(.000)$ \\
Leadership & $.3190^{* * *}$ & $17.51(.000)$ \\
Vote for CiU in 1995 & $.6840 *$ & $4.40(.036)$ \\
Constant & .0580 & $.02(.902)$ \\
\hline Model diagnosis & & \\
$\mathrm{N}$ & 622 & \\
Model Chi-Square & $213.51 * * *$ & \\
Overall correct prediction & $89.55 \%$ & \\
$\mathrm{R}_{\mathrm{LA}}^{2}$ 100 & $37.30 \%$ & \\
\hline
\end{tabular}

*** Significant at 0.001 level; * significant at 0.05 level

The reported vote in the 1995 elections is also significant at the 0,05 level indicating that, other things being equal, people who voted for CIU has a higher probability to approve the government than people who voted for other parties. This fact seems to insinuate the existence of a reciprocal effect between government approval and vote intention: people who approve the government tends to vote for the incumbent party and people who voted last time for the party now in office tends to approve its record. 
Due to the fact that the logistic model is not lineal it is difficult to grasp what are the variables that have a major impact in governmental approval, because it is something that varies depending on the other variable values. For example, one typical citizen, with middle perceptions about government record in economic, cultural and social policies, that gives an evaluation to the President equal to the mean, and that voted for CiU in 1995, has a probability to approve the government of $0.95 .^{23}$. In contrast, if he did not vote for $\mathrm{CiU}$, the probability descents until 0.90 . Then, for this moderate citizen there is only a difference of $5 \%$ in the approval probability depending on his vote in the last autonomous election. However, this difference is not always the same. For a more pessimistic individual, with a negative evaluation of economic, cultural and social policies and also with a negative evaluation of the president (for example, -1 in each factor and 4 for leadership) the difference is bigger. He has a probability of 0.40 to approve the government if he had voted for CIU in the previous election and 0.15 if he had not.

The best way to decode the information provided by the model is displaying graphically the conditioned effects of each variable subject to specific values of the rest of variables. Figure 3 represents the conditioned effects of economic policy evaluations on government approval subject to leadership for those who do not voted for the incumbent (being the rest of the variables fixed to the mean). It shows a clear asymmetry with respect to the mean. Concretely, the effects of an increase of one unity in the value of the economic evaluation are bigger when the citizen has a negative perception of them than when he has a positive one. It also shows that, when economic policy evaluations are negative, the effect of an increase of leadership is very important while it is far smaller when policy evaluations are positive.

Figure 4 show the impact of economic perceptions conditioned to reported vote. It can be observed that even though the probability to approve the government record is higher for those voted the incumbent in the last autonomous elections, the impact of the economy is bigger for those who voted other parties.

Figure 5 display the impact of the economy on government approval conditioned to social policy evaluations for people did not support the government party in 1995 elections. As it can be seen, the probability to approve the government when the 
evaluation of economic policies is low depends on the perceptions on how well the government is doing with respect to social policies. For instance, when the economic evaluation is -2 the probability to support the incumbent ranges from 0.15 to 0.89 depending on the social factor values. Instead, when the economic evaluation is 2 , it runs from 0.85 to 0.99 . That is, the effect of the perception of social policy performance is approximately five times bigger at the left side of the graph (when there is a bad perception of the economy) than at the right side (when the economy is seen as good).

The last figure, Figure 6, exhibits also the effects of the economy but this time conditioned by the cultural factor. At a first glance, we can grasp that the pattern of the graph is quite different from the previous. The asymmetry is lower in this case, as the lines are disposed covering all the four quarters of the diagram, though it is still present.

In sum, from all of the figures we can deduce that opinions on government responsibility differ depending on citizen's perceptions of the state of a particular group of policies. For instance, those who perceive the economic situation as deteriorating are more likely to hold the government responsible for it than those who consider the economic situation positive. Therefore, voters are disposed to give more weight to negative information and consequently, tend to punish in a heavily way the incumbent when things go bad rather than reward him when they go well. These results conform Bloom and Price (1975) findings in the sense that economic downturns hurt congressional candidates of the inparty but upturns do not help them ${ }^{24}$. There is also a theoretical support for this bias. Lau (1982, 1985) draws upon the literature in cognitive psychology to provide both empirical evidence and theoretical justification for negativity bias operating at the level of attitudes $^{25}$. In our case, the patterns of the graphs enlighten the existence of the grievance asymmetry. 
Figure 3: Effects of economic evaluation on government approval conditionned to leadership

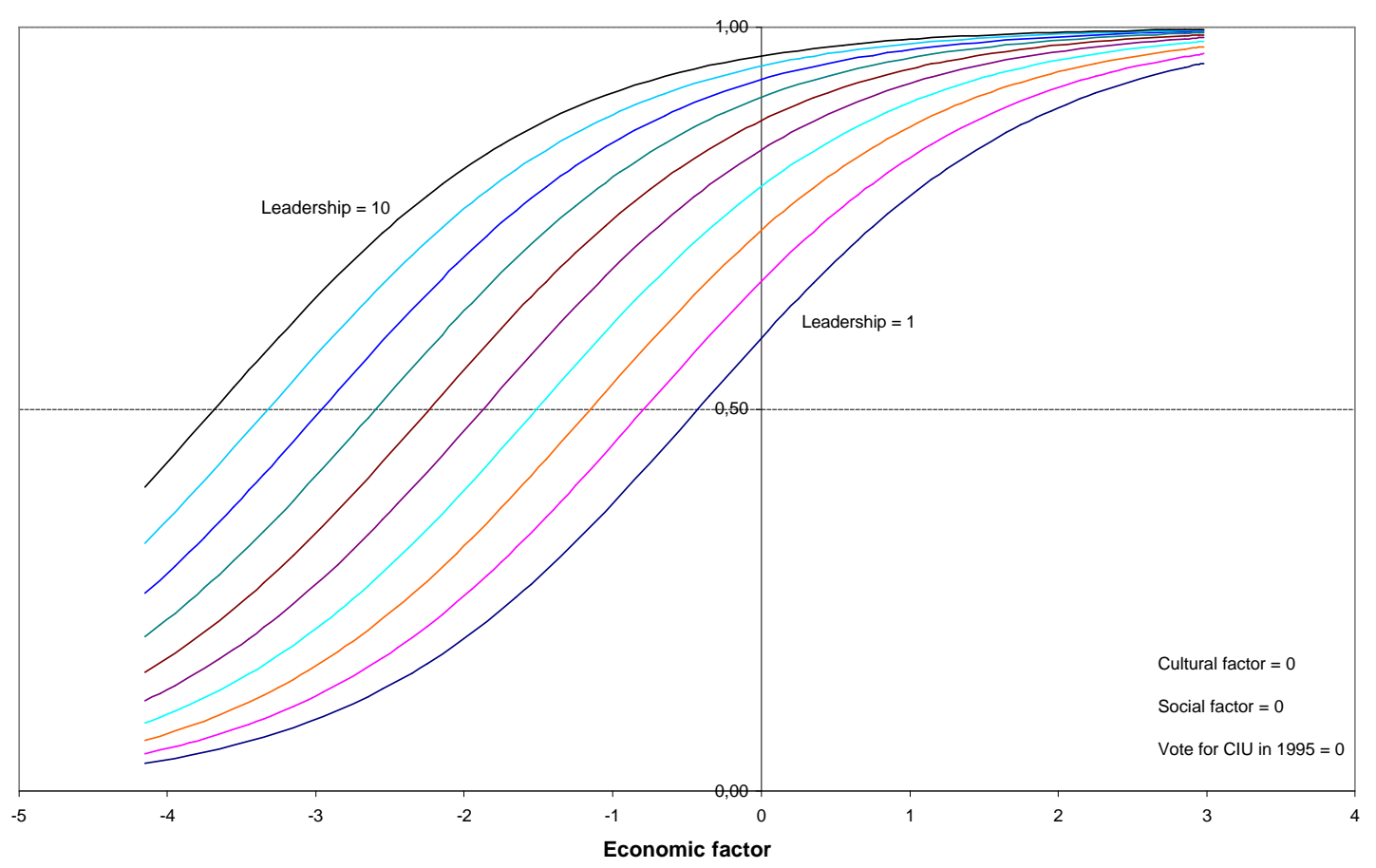

Figure 4: Effects of economic evaluation on government approval conditionned to reported vote

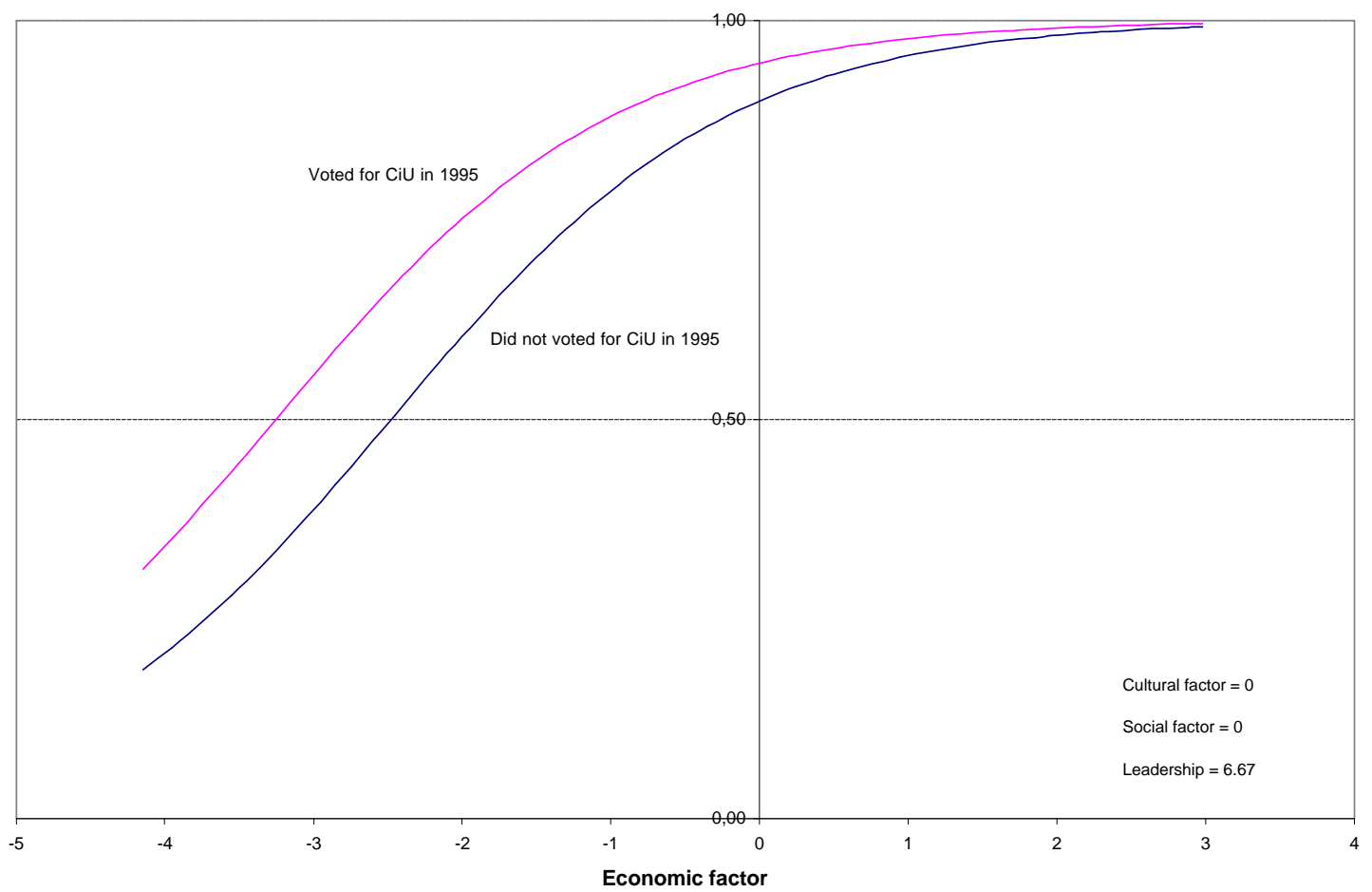


Figure 5: Effects of economic evaluation on government approval conditionned to social evaluation

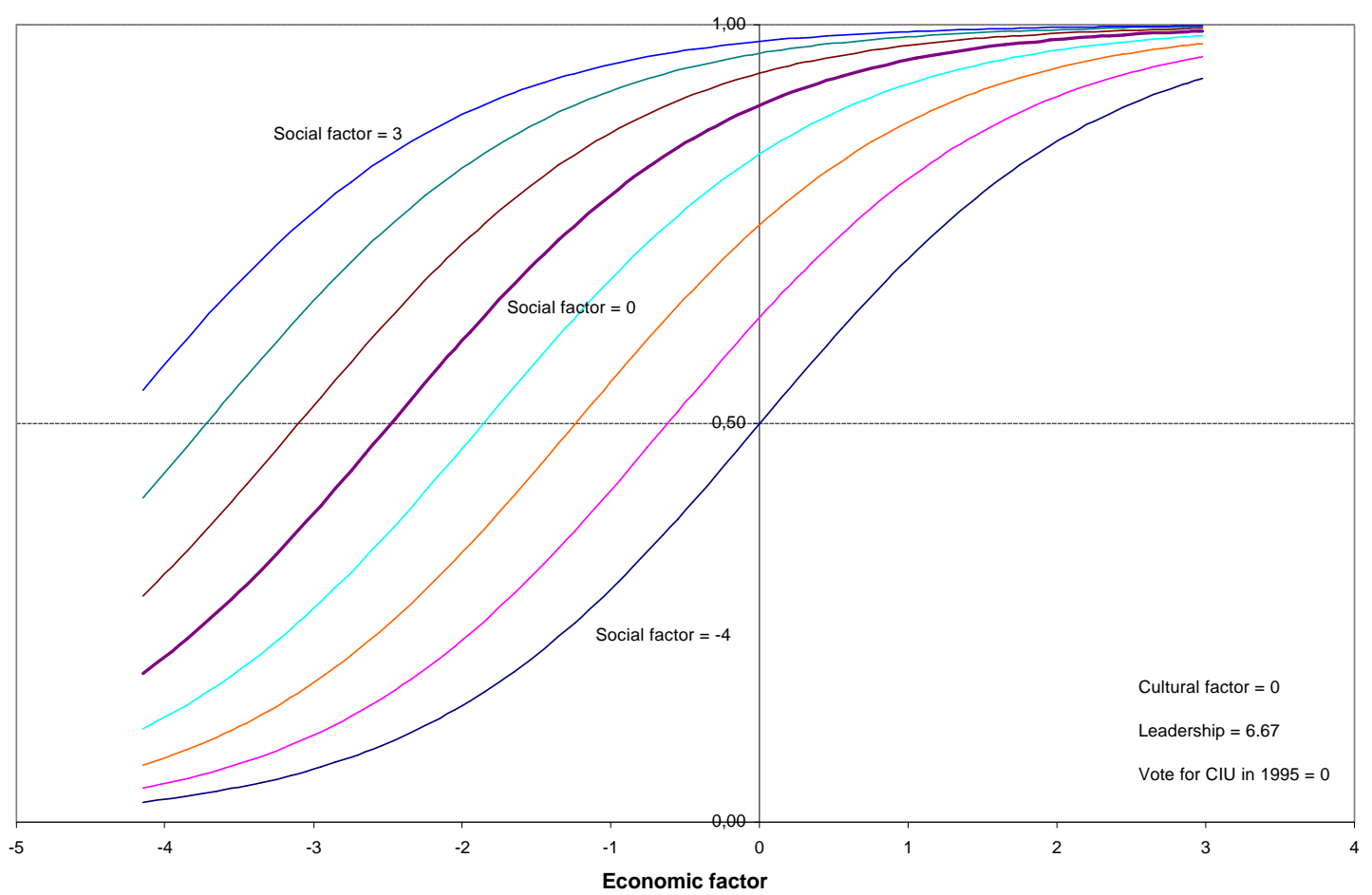

Figure 6: Effects of economic evaluation on government approval conditionned to cultural evaluation

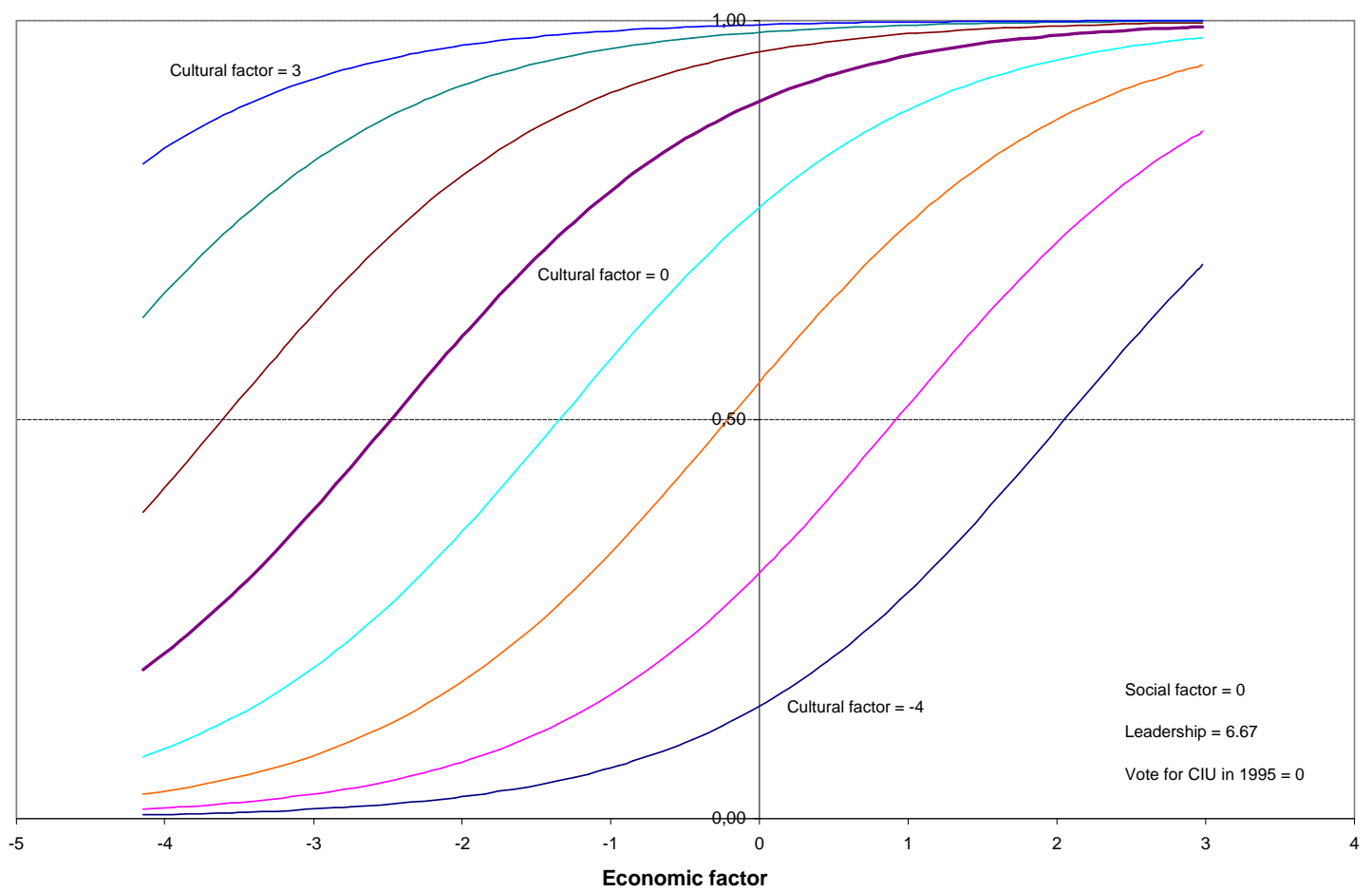




\section{CONCLUSION}

In this paper we have examined if economic variables influence popular support for subnational governments. In a first stage, using the classical political-economic aggregate model, we have estimated a model with macroeconomic indicators and variables about economic perceptions. In this function, we have also introduced variables measuring specific political events in order to control the previous results. Secondly, we have validated our aggregate findings using a micro-level approach, and we have also tried to bring some light into the attribution of responsibility debate. At this respect, we have considered the evaluations of government performance on certain issues in order to clarify the factors that drive government support.

The empirical results contained in this study clearly shows the following points:

- The responsibility hypothesis works in political institutions without explicit macroeconomic competencies. In consequence, it seems that the relation between responsibility and economic power is no so straightforward as it could be thought. The foundations of the traditional reward-punishment hypothesis remain unclear. An alternative way to see if people attribute economic changes to the incumbent may be to use evaluations of the policies, where the attribution of responsibilities looks clear. Our analysis has showed that, in the Catalan case, there are three factors underlying policy evaluations: the economic, the cultural and the social, being the first the most important of them. All affects Catalan government approval, even when some variables of control are introduced.

- Support to sub-national governments appears to be influenced by regional economic indicators and not by the national ones. The research has shown that Spanish economic indicators are not significant, even though they are more enlightened by the media than Catalan data. Therefore, it seems that there are different economic perceptions among the regions composing a country. The reason could be that, although mass media plays an important role, citizens' perceptions are mainly coloured by their experiences and nearby context (i.e., social, political, etc). 
- The grievance asymmetry hypothesis is empirically grounded. Our results provide an empirical support for a negativity disposition on government popularity. An economy in slump harms the incumbent's support but an economy that is improving does not benefit the government popularity in the same way. The graphical displays presented in this paper visualise clearly these findings.

- In contexts of multilevel governance, the attribution of responsibility is diffused. The Catalan popularity function represents a good example of model party support in a situation of subsidiary and, there, we have found that the state of the regional economy affects the support for the regional government despite its scarce economic competencies. The European Union is undergoing a period of fundamental change and the patterns and factors underlying the Catalan government support could be extrapolated to the future situation in Europe. Although most of macroeconomic competencies would be centralised in a supranational institution, with the existence of an unique Unit Currency and an European Central Bank, our study suggest that the most probable situation is that in each European country citizens would continue attributing responsibilities to their State government. 


\section{References}

Alesina, A. \& Rosenthal, H. (1995). Partisan politics, divided government, and the economy. Cambridge, Cambridge University Press.

Anderson, C. (1995). Blaming the government. Citizens and the economy in five European democracies. London, M.E.Sharpe.

Anderson, C.(1999). Economic voting and political context: a comparative perspective. Forthcoming in Political Studies.

Bellucci, P. (1991). Italian economic voting: a deviant case or making a case for a better theory?. In Lewis-Beck (eds.), Economics and politics : the calculus of support. Ann Arbour, University of Michigan Press.

Bellucci, P. (1999). Economic issues and economic voting in a democratic transition: the 1994 and 1996 Italian national elections. ECPR Joint Sessions of Workshops, Mannheim, Germany.

Beck, N. (1991). Comparing dynamic sophistication: the case of presidential approval, Political Analysis 3: 37-51.

Bloom, H. \& Price, H. (1975). Voter Response to Short-run Economic Conditions, American Political Science Review 69:124-54.

Budge, I. \& Farlie, D. (1983). Explaining and predicting elections: issue effects and party strategies in twenty-three democracies. London, George Allen and Urwin.

Butler, D. \& Stokes, D. (1976). Political Change in Britain. New York, St Martin's Press.

Canals, R. M., Pallarès, F. \& Virós, R. (1991). Els catalans davant la consulta electoral. In Equip de Sociologia Electoral (eds.), Estudis electorals/10. L'electorat català a les eleccions autonòmiques de 1988: opinions, actituds $i$ comportaments. Barcelona, Publicacions de la Fundació Jaume Bofill.

Clarke, H. D. \& Mariane C. S.(1995). Economic evaluations, prime ministerial approval and governing party support: rival models reconsidered, British Journal of Political Science 25: 145-170.

Clarke, H.D \& Stewart, M. (1996). Economists and Electorates: The Subjective Economy of Governing party Support in Canada, European Journal of Political Science 29:191-214. 
Eulau, H. \& Lewis-Beck, M. S. (eds.) (1985). Economic conditions and electoral outcomes in the United States and western Europe. New York, Agathon Press.

Fossas, E. \& Colomé, G. (1993). Political parties and institutions in Catalonia. Barcelona, Institut de Ciències Polítiques i Socials.

Fraile, M. (1999). Explaining 14 years of social-democratic power: economic performance, electoral support and political context in democratic Spain (1982-1996). ECPR Joint Sessions of Workshops, Mannheim, Germany.

Harvey, A. C. (1981) The econometric analysis of time series. Oxford, Philip Allan.

Heath, A., Jowell, R., Evans, G., Fields, J. \& Witherspoon, S. (1991). Understanding Political Change: The British Voter 1964-1983. Oxford. Pergamon.

Hendry, David S. \& J.F. Richard (1983) "The econometric analysis of economic time series (with discussion)", International Statistics Review, 51:11-63.

Key, Jr. V. O. (1968). The responsible electorate: Rationality in presidential voting, 1936-1960. New York, Vintage Books.

King, A. (1997). Why Labour won, at last. In King, A. (eds), New Labour triumphs: britain at the polls. London, Chatham House.

Lafay, J.D. (1991). Political Dyarchy and popularity functions : lessons from the 1986 French experience. In Norpoth, H., Lewis-Beck, M. S. \& Lafay, L.D (eds.), Economics and politics: the calculus of support. Ann Arbour, University of Michigan Press, 123-140.

Lau, R. (1982). Negativity in political perceptions, Political Behaviour 4:353-78.

Lau, R. (1985). Two explanations for negativity effects in political behaviour, American Journal of Political Science 29:119-38.

Lewis-Beck, M. S. \& Eulau, H. (1985). Economic conditions and electoral outcomes in the United States and Western Europe. New York, Agathon.

Lewis-Beck, M. S. (1988). Economics and elections: the major western democracies. Ann Arbor, Michigan University Press.

Leyden, K. M. \& Borrelli, S. A. (1995). The Effect of State Economic Conditions on Gubernatorial Elections: Does Unified Government Make a Difference?, Political Research Quarterly 48(2): 253-274.

Mckuen, M., Erikson, R. \& Stimson, J. (1992). Peasants or bankers? The American electorate and the U.S. economy, American Political Science Review 86: 597-611. 
Mills, T. C. (1990). Time series techniques for economists. Cambridge, Cambridge University Press.

Montero, J. R. \& Font, J. (1991). El voto dual: lealtad y transferencias de votos en las elecciones autonómicas. In Equip de Sociologia Electoral (eds.), Estudis electorals/10. L'electorat català a les eleccions autonòmiques de 1988: opinions, actituds i comportaments. Barcelona, Publicacions de la Fundació Jaume Bofill.

Montero, J. R. \& Torcal, M. (1992). Política y cambio cultural en España: una nota sobre la dimensión postmaterialista, Revista Internacional de Sociología $1: 61-99$.

Mueller, J. E. (1970). The presidential popularity from Truman to Johnson, American Political Science Review 64: 18-39.

Nannestad, P. \& Paldam, M. (1994). The VP-function: a survey of the literature on vote and popularity functions after 25 years, Public Choice 79: 213-245.

Nannestad, P. \& Paldam, M. (1997). The grievance asymmetry revisited: A microestudy of economic voting in Denmark, 1986-92, European Journal of political Economy 13: 81-99.

Norpoth, H., Lewis-Beck, M. S. \& Lafay, L.D. (1991). Economics and politics : the calculus of support. Ann Arbour, University of Michigan Press.

Padró-Solanet, A. (1993). Spatial models and campaign issues. The case of Spain. ECPR Joint Sessions of Workshops, Leiden, Holland.

Paldam, M. (1991). How robust is the vote function? A study of seventeen nations over four decades. In Norpoth, H., Lewis-Beck, M. S. \& Lafay, L.D (eds.), Economics and politics: the calculus of support. Ann Arbour, University of Michigan Press, 9-31.

Pallarès, F.\& Font, J. (1995). The Autonomous elections in Catalonia (1980-1990). Barcelona. Institut de Cienciès Polítiques i Socials.

Powell, G. B. \& Whitten, G. (1993). A cross-national analysis of economic voting: taking account of the political context, American Journal of Political Science 37: 314-334.

Riba, C. (1995). Vot dual $i$ abstenció diferencial. Doctoral Thesis presented at the Departament de Ciència Política i de Dret Públic de la Universitat Autònoma de Barcelona. Bellaterra, Publicacions de la Universitat Autònoma de Barcelona (microfiche).

Sanders, D., Marsh, D. \& Ward, H. (1987). Governmental popularity and the Falklands war: A reassessment, British Journal of Political Science 17: 281-313. 
Sanders, D. (1998). The Real Economy and the Perceived Economy in Popularity Functions: How Much do Voters Need to Know? A Study of British Data, 1974-97. Paper presented at the Barcelona Conference on Vote and Popularity Functions.

Seyd, P. (1997). Tony Blair and New Labour. In King, A. (eds.), New Labour triumphs: Britain at the polls. London, Chatham House.

S申rensen, R. J. (1987). Macroeconomic policy and government popularity in Norway, 1963-1986, Scandinavian Political Studies 10:301-21.

Vallès, J. M. \& Molins, J. M. (1990). La vida electoral a Catalunya : eleccions i referèndum entre 1982 i 1988. In Equip de sociologia electoral (eds.), Estudis Electorals/9. Atlas Electoral de Catalunya 1982-1988. Barcelona. Publicacions de la Fundació Jaume Bofill.

Weatherford, M. S. (1983). Economic voting and the symbolic politics argument: a reinterpretation and synthesis, American Political Science Review 73: 158174. 


\section{Notes}

${ }^{1}$ For overviews, see Lewis-Beck (1988) and Nannestad \& Paldam (1994).
${ }^{2}$ In this sense, Sprensen (1987) finds weak and contradictory effects in the Norwegian case; Lewis-Beck
(1988) points out that economic vote diminishes when the complexity of the coalition government
increases; for the Italian case, Bellucci (1991) shows that the traditional reward-punishment pattern has
not been working during the pentapartito government period; however, it seems to work in the newly
institutional context set in the nineties (Bellucci,1999).

${ }^{3}$ The Catalan government, named Generalitat, has assumed competencies in issues such as culture, research, tourism, mountains, fishing, publicity, sport, public works, guardianships of minors, foundations and associations. On other issues, it only assumes the execution of the state legislation: penitentiary, labour, international exhibitions (Fossas \& Colomé, 1993: 21). In relevant issues such as industry, agriculture and trade, education, media, health or police force, the Catalan government has ruling powers but within the state laws. It can be seen that issues directly related with sovereignty (nationality, international affairs, armed forces, and monetary system), certain branches of law (commercial, penal and labour) or issues related to macroeconomic policies or to the general planning of the economic activity correspond to the State.

4 The Statute of Autonomy has a double nature: on one side, it is a Law of the Parliament, and on the other, "the essential institutional rule of each AA.CC." as the Spanish Constitution itself states (art. 147.1) (Fossas \& Colomé, 1993).

${ }^{5}$ Convergencia i Unió ( $\left.\mathrm{CiU}\right)$ is a pre-electoral coalition, composed by two parties: Convergencia Democràtica de Catalunya (CDC), near to liberal ideology, and Unió Democràtica de Catalunya (UDC) that is a Christian-democratic party.

${ }^{6}$ The CiU's mandate has been defined on the basis of the ratification of Jordi Pujol as the President of the Generalitat as a guarantee for the continuity of government action (through his actions, his policies and his image). Furthermore, the access to institutional resources has allowed $\mathrm{CiU}$ to strengthen its organisational structure and widen its electoral "appeal" (in resources, utility and image).

${ }^{7}$ In industrialised areas the left forces receive the major support while in the rural areas the nationalist coalition get better results.

${ }^{8}$ It is known as differential abstention the electoral behaviour consisting in voting in the general elections and to abstain in the autonomous ones. Dual vote means to vote for different parties in different type of elections.

${ }^{9}$ We want to remind that European Union issues have a lot of importance in Spanish politics. After a long period of dictatorship, the entrance in the European Community in 1996 was understood as the end of Spanish isolation.

${ }^{10}$ Our first purpose was to estimate a function that covered the whole period of nationalist government (from 1980 until today), but we came across the problem of data frequency. While during the 80 s, survey data related to the Catalan government and subjective economic perceptions was almost non-existent, from 1996 to 1998 the frequency of this data is really irregular. Therefore, our choice has been to use a unique source of data with a monthly periodicity. The data analysed come from LINE STAFF election surveys.

${ }^{11}$ The 1994 European Elections in the Spanish case were seen for some analysts as an opportunity for citizens to show their satisfaction or dissatisfaction with the current incumbent. In 1996, the Popular Party won the General elections.

${ }^{12}$ They start with Filesa, a case of irregular financing of the socialist party, followed by other corruption cases involving highly-placed officers of public institutions (the cases Roldan, Rubio, Banesto etc.)

${ }^{13}$ Although we have called Cullell to a political scandal, it is worth mention that this case not stands only for a specific event. During 1994, several cases of corruption damaged the image of the Catalan government in a Spanish context of political and social tension. We have created several dummies in order to capture the effects of these damaging events, ranging from one to 8 months (between May 1994 and November 1994).

${ }^{14}$ A series is weakly stationary if its mean and variance are time invariant and its auto-covariances of lags $i$ and $j$ depend only of the length of the time lag separating $i$ and $j$. See Terence C Mills (1990:64).

${ }^{15}$ Dickie- Fuller test is a simple t-ratio, but with non-standard critical values, which vary depending upon whether one includes a constant or deterministic trend in the regression analysis that generates the 
unit-root test statistic (Clarke et al., 1996 :20). The null hypothesis is that series has a unit root. The rejection of this hypothesis implies that the series is stationary.

${ }^{16}$ It basically consists on trying to estimate a general and unrestricted specification (greatest number of variables, lags) that exhaust much of the information we need. As may be expected the resultant model includes regression coefficients statistically non-significant. Accordingly, the independent variables associated with those coefficients are excluded from the model and a new shorter model is re-estimate, until we find the appropriate one. In addition to this method, we devised a complementary routine that followed a variable to variable basis. Each of the previous independent variables and their lags were introduced as a single estimator in the model, generating a list of variables which influences popular support in an autonomous manner. This routine did not change the previous model, but it has been useful in guaranteeing that our model is well specified.

${ }^{17} \mathrm{We}$ are conscious about the problem of heteroscedasticity of our model. After having checked what is the problem in model specification, we consider that heteroscedasticity may be produced by the political variable. This dummy variable takes value 1 between May 1994 and November 1994, which constitutes a long period for a dummy variable. We have estimated a different dummy for each month separately and we have seen that some of them were not working. Because of parsimonious specification, we decide to leave our first choice. Cullell taking 1 between-November 1994.

${ }^{18}$ As Paldam points out, the VP-function is a function that is on the one hand unstable and, on the other hand, often highly significant (1991:28).

${ }^{19}$ Recursive regressions involve basically estimating the whole model with successive periods of estimation which grow longer in each estimation. On the other hand, rolling regression involves successively re-estimating the model for established periods of, say 25 points. First, we estimate a model for the first 25 points, then, from 2 to 26 and successively until the last point.

${ }^{20}$ The data proceeds from a Line Staff study (Ref. 6576-3) commissioned by the Generalitat of Catalonia and conducted in November 1998.

${ }^{21}$ To test empirically the association between the factors and the dimensions of the Catalan political space, the best strategy would be to calculate the Pearson correlation among the three factors we found and some variables that express the individual positions of citizens in this political space. Unfortunately, there is not a question in the survey about self-location in the Left/Right scale. Neither is in the nationalist scale. There is only one question about the perception that citizens have of the Left/Right position of the governing coalition CIU. This can be used in some sense as a rough proxy for the selfplacement in the Left/Right dimension. We can understand than those who consider CIU as a right political force are the leftist, than those who consider it as a centre force are the centrists, and than those who consider the coalition as a left force are the rightists. The correlation between this approximate selfplacement and the economic and social factors is very significant, though small. Their sign tell us that left-wing people evaluate badly the economic and social task of the government than right-wing people do.

${ }^{22}$ Because we do not have questions about party identification, party preference or feeling thermometers in our sample, we used a dummy, the recorded vote for $\mathrm{CiU}$, as a proxi for party identification. As a more accurate indicator of it, we also used another dummy recording the citizens who express the intention to vote for the same party they voted in the last elections. However, in our analysis the results obtained with both proxies were quite similar.

${ }^{23}$ The economic, cultural and social variables are standardised. As a result, its mean is zero and its standard deviation 1. Negative values correspond to evaluations below the mean and positive values over the mean. The president evaluation variable ranges from 1 to 10 , being the mean 6.67.

${ }^{24}$ Before Bloom \& Price, Mueller (1970) looked at a different type of assymetry. Mueller's grievance of assymetry implies that voters react to an economic variable when the variable rates above or below a certain level.

${ }^{25}$ Some assumptions about the theoretical support of the grievance asymmetry and the way how it can be modelled are discussed by Nannestad \& Paldam (1997). 